\title{
Pulmonary infections in the returned traveller
}

\author{
Ashleigh Trimble ${ }^{1,2^{*}}$, V. Moffat ${ }^{3}$ and A. M. Collins ${ }^{2,4}$
}

\begin{abstract}
Pulmonary infections in the returned traveller are a common presentation. A wide variety of infections may present with pulmonary symptoms. It is important for clinicians to differentiate the cause of these symptoms. The risk of contracting certain travel-related pulmonary diseases depends on travel destination, length of stay, activities undertaken and co-morbidities. Some pathogens are found worldwide, whilst others are related to specific locations. This review article will discuss the approach to diagnosing and treating pulmonary infections in the returned traveller.
\end{abstract}

Keywords: Travel, Traveller, Pulmonary infections, Tropics, Respiratory infections

\section{Background}

International travel has steadily increased over the last few decades, and is no longer only for the wealthy and healthy. The number of travellers reached more than one billion for the first time in 2012 and continues to rise [1]. There are many risk factors that increase the likelihood of developing a travel-related illness and this review will focus on pulmonary-related infections (Table 1) [2-4]. Many illnesses are self-limiting and are a result of common pulmonary viruses that are prevalent worldwide $[3,5]$ but in certain circumstances travel-related pulmonary infections are serious and have potentially fatal implications, and can even cause epidemics.

Air travel has shown how efficiently pulmonary infections can be transmitted. Data suggests the risk of disease transmission to a symptom-free passenger within the aircraft cabin is associated with sitting within 2 rows of a contagious passenger for a flight time of more than $8 \mathrm{~h}$. This association is mainly derived from investigations of in-flight transmission of tuberculosis (TB) [6]. Aircraft cabin ventilation appears to be a key factor enabling disease transmission. This was highlighted by the spread of severe acute respiratory syndrome (SARS) during a short-haul flight in 2002 [5]. With sea travel (especially cruising) becoming more popular, the ageing

\footnotetext{
* Correspondence: a.trimble@nhs.net

${ }^{1}$ Crosshouse Hospital, Kilmarnock Road, Crosshouse KA2 OBE, UK

${ }^{2}$ Respiratory Infection Group, Liverpool School of Tropical Medicine,

Pembroke Place, Liverpool L3 5QA, UK

Full list of author information is available at the end of the article
}

population of travellers with multiple pre-existing conditions is also a concern.

Clinicians should be aware of particular diseases that may present in the returned traveller and rank their diagnostic likelihood based on destination, length of stay and symptom duration (Tables 2 and 3 ).

Pneumonia is a frequent cause of fever amongst returned travellers [7]. Awareness of travel locations may be key to identifying the organism responsible, and polymerase chain reaction (PCR) testing is very important to look for atypical etiologies. Routinely, patients are started on antibiotics based on local guidelines for communityacquired pneumonia. It is unlikely these regimens will contain appropriate first-line therapy or be of sufficient duration to cover for pneumonias caused by Coxiella burnettii (Q fever) [8] or Burkholderia pseudomallei (melioidosis), which have been isolated in recent outbreaks that have occurred in Europe and South East Asia [9].

Pulmonary infections are diagnosed in up to $24 \%$ of returned travellers with fever, making it as common as travellers' diarrhea, with influenza being the most common vaccine-preventable infection acquired (vaccine protective against $\mathrm{H} 1 \mathrm{~N} 1, \mathrm{H} 3 \mathrm{~N} 2$ and two influenza $\mathrm{B}$ virus strains) $[10,11]$. Pre-travel advice should be that travellers with co-morbidities should be vaccinated against both seasonal influenza virus and pneumococcus [12]. It should be noted that the influenza vaccine does not currently offer protection against the most recent strains causing epidemics (H5N1, H7N9) and 
Table 1 Specific Risk factors

\begin{tabular}{|c|c|c|}
\hline Risk activities & Common & Occasional \\
\hline \multicolumn{3}{|l|}{ Bites } \\
\hline Tick & & Q fever \\
\hline Mosquitos & $\begin{array}{l}\text { Tropical eosinophilia } \\
\text { (Wuchereia bancrofti } \\
\text { and Brugia malayi) }\end{array}$ & Dirofilarisis \\
\hline Animal & $\begin{array}{l}\text { Avian influenza, } \\
\text { Nipah virus, Hantaan } \\
\text { virus, MERS }\end{array}$ & $\begin{array}{l}\text { Q fever, tularemia, } \\
\text { plague, SARS }\end{array}$ \\
\hline $\begin{array}{l}\text { Dust exposure } \\
\text { (e.g., caves or } \\
\text { deserts) }\end{array}$ & $\begin{array}{l}\text { Coccidioimycosis, } \\
\text { histoplasmosis }\end{array}$ & \\
\hline Cruise ships/resorts & Legionella & \\
\hline Rural/Farm & Q fever & \\
\hline Soil & $\begin{array}{l}\text { Strongyloidiasis, } \\
\text { hookworm, ascariasis }\end{array}$ & Melioidosis \\
\hline $\begin{array}{l}\text { Fresh-water } \\
\text { exposure }\end{array}$ & $\begin{array}{l}\text { Schistosomiasis, } \\
\text { leptospirosis }\end{array}$ & \\
\hline \multicolumn{3}{|l|}{ Ingestion } \\
\hline $\begin{array}{l}\text { Undercooked/ } \\
\text { raw food }\end{array}$ & & $\begin{array}{l}\text { Paragonimus, } \\
\text { toxocariasis, } \\
\text { hydatidosis }\end{array}$ \\
\hline Sexual exposure & HIV & \\
\hline \multicolumn{3}{|l|}{ Host factors } \\
\hline Immunocompromised & Tuberculosis & \\
\hline
\end{tabular}

SARS severe acute respiratory syndrome, MERS Middle Eastern respiratory syndrome, HIV human immunodeficiency virus

the risk of acquiring the illness depends on season of travel and length of stay in affected areas [13].

In this review, we will discuss various pulmonary infections that are more common in returned travellers. A clear and thorough approach to a symptomatic returned traveller is an essential skill for the acute/general physician and general practitioner (Table 4). Particular attention should be given to infections that may spread by human-to-

Table 2 Incubation periods of pulmonary infections

\begin{tabular}{ll}
\hline Incubation Period & Infection \\
\hline Short (<10 days) & Viral: influenza, SARS, MERS, Nipah \\
& Bacterial: common organisms causing \\
& pneumonia (Streptococcus pneumoniae, \\
& Haemophilus influenzae), melioidosis, \\
& Legionellosis, plague, pertussis, diphtheria \\
& Fungal: histoplasmosis \\
Medium (10-21 days) & Viral: MERS, Nipah, hantavirus \\
& Bacterial: pertussis, melioidosis \\
& Fungal: histoplasmosis, coccidioidomycosis \\
& Eosinophilic: ascariasis, hookworm, strongyloides, \\
& toxocariasis \\
& Bacterial: Q fever, TB \\
& Eosinophilic: schistosomiasis, hydatidosis, \\
& dirofilariasis, paragonomiasis, Wuchereia bancrofti, \\
& Brugia malayi
\end{tabular}

SARS severe acute respiratory syndrome, MERS Middle Eastern respiratory syndrome, $T B$ tuberculosis human transmission. Clinicians should be aware of where to source information should they suspect a travel-related infection or if they have concerns for public health. Infections related to travel are constantly evolving and it is important for clinicians to remain up to date with current disease outbreaks and management recommendations.

\section{Pulmonary infections caused by viruses and bacteria}

Upper pulmonary infections are more common than lower pulmonary infections. In general, the types of pulmonary infections that affect travellers are similar to those in non-travellers, and exotic causes are rare [2, 13, 14]. An Australian study collected data over a 3-year period; it showed around $28 \%$ of Australian travellers returning from Asia developed an acute pulmonary infection within $72 \mathrm{~h}$ (defined as an illness episode involving the presence of at least two upper pulmonary symptoms; e.g., sorethroat, coryza). This translates to an incidence of 106.4 per 10,000 traveller days. PCR testing on these travellers was analyzed for influenza A and B virus, adenoviruses, respiratory syncytial virus (RSV), picornaviruses and parainfluenza viruses 1,2 , and 3 . Only $1 \%$ of these travellers acquired influenza A virus, with no data for the other detectable viruses included [15].

There is evidence that contracting a common upper pulmonary virus potentiates the risk of contracting a tropical disease as well. A study in 2008 [16] showed that during an epidemic of chikungunya in India, $87 \%$ of confirmed cases were also co-infected with RSV and another upper respiratory virus, $41 \%$ were co-infected with RSV alone and 9\% were co-infected with influenza virus and adenovirus. It is likely that a parallel outbreak of pulmonary viral infections during this time resulted in higher morbidity and mortality during this epidemic.

Bacterial pathogens are generally not related directly to a particular travel destination. Streptococcus pneumoniae, Mycoplasma pneumoniae, Haemophilus influenzae, and Chlamydophila pneumoniae are the most common organisms known to cause pneumonia throughout the world and risk of infection is not directly related to travel. More specific illnesses caused by C. burnettii ( $\mathrm{Q}$ fever), Legionella pneumophila (Legionella), Bordetella Pertussis (pertussis), Corynebacterium diphtheriae (diphtheria) and Leptospira (leptospirosis) are normally a result of an epidemic within a country [2, 10, 14]. This list may be very relevant to the treating clinician.

Travel to international mass gatherings is a proven risk factor for the spread of pulmonary infection. For example, during pilgrimage to Mecca, pneumonia caused by $S$. pneumoniae is the leading cause of hospitalization and intensive care unit admissions during the Hajj (nearly $40 \%$ of patients). Out of 300 participants less than $5 \%$ had been vaccinated despite $65 \%$ being eligible. 
Table 3 Causes of pulmonary infections associated with specific geographical areas

\begin{tabular}{|c|c|c|c|}
\hline Geographical Area & Common & Occasional & Rare but important \\
\hline Sub-Saharan Africa & $\begin{array}{l}\text { HIV-associated } \\
\text { pulmonary infections, TB }\end{array}$ & $\begin{array}{l}\text { Katayama syndrome, tropical pulmonary eosinophilia } \\
\text { (Wuchereia bancrofti), Loeffler's syndrome (hookworm, } \\
\text { strongyloides) hydatidosis }\end{array}$ & $\begin{array}{l}\text { Histoplasmosis, pneumonic plague, } \\
\text { paragonomiasis }\end{array}$ \\
\hline $\begin{array}{l}\text { North Africa, Middle East } \\
\text { and Mediterranean }\end{array}$ & & $\begin{array}{l}\text { Q fever, tropical pulmonary eosinophilia (Wuchereia } \\
\text { bancrofti) Loeffler's syndrome (hookworm, ascariasis, } \\
\text { strongyloides) hydatidosis, toxocariasis }\end{array}$ & MERS \\
\hline $\begin{array}{l}\text { Eastern Europe and } \\
\text { Scandinavia }\end{array}$ & Legionellosis & Pertussis, toxocariasis & Hantavirus, tularemia \\
\hline South and Central Asia & diphtheria, TB, avian flu & $\begin{array}{l}\text { Melioidosis, Loeffler's syndrome (hookworm, ascariasis, } \\
\text { strongyloides) hydatidosis }\end{array}$ & Nipah virus \\
\hline Southeast Asia & avian flu & $\begin{array}{l}\text { Melioidosis, tropical pulmonary eosinophilia (Brugia } \\
\text { malayi), Loeffler's syndrome (strongyloides, hookworm), } \\
\text { leptospirosis, diphtheria }\end{array}$ & $\begin{array}{l}\text { SARS, hantavirus, Nipah virus, } \\
\text { dirofilariasis, Katayama syndrome, } \\
\text { paragonomiasis }\end{array}$ \\
\hline Northern Australia & & Q fever & Melioidosis, dirofilarisis, pertussis \\
\hline $\begin{array}{l}\text { Latin America and } \\
\text { Caribbean }\end{array}$ & & $\begin{array}{l}\text { Coccidioidomycosis } \\
\text { histoplasmosis, leptospirosis, diphtheria, tropical pulmonary } \\
\text { eosinophilia (Wuchereia bancrofti), Loeffler's syndrome } \\
\text { (ascariasis, strongyloides), hydatidosis, toxocariasis }\end{array}$ & Hantavirus, dirofilariasis \\
\hline North America & $\begin{array}{l}\text { Legionellosis, pertussis, } \\
\text { diphtheria }\end{array}$ & $\begin{array}{l}\text { Coccidioidomycosis } \\
\text { histoplasmosis, toxocariasis }\end{array}$ & Dirofilariasis, Q fever \\
\hline
\end{tabular}

HIV human immunodeficiency virus, SARS severe acute respiratory syndrome, MERS Middle Eastern respiratory syndrome, TB tuberculosis

Improved pre-travel vaccination advice could prevent diseases for many travellers [12].

\section{Influenza}

Particular attention should be paid to travellers returning from influenza-endemic areas, taking into account newly reported sub-types. The burden of influenza occurs in the winter months in temperate regions, in the Northern Hemisphere from November to April and the Southern Hemisphere from April to October. In the tropics, the virus circulates at a low level all year round [17]. Influenza is diagnosed from viral throat swabs using real time PCR (rt-PCR) that can differentiate particular influenza subtypes [18].

Avian influenza sub-type H5N1 virus has caused death in humans since 1997, predominately in Asia and North East Africa, with a current upsurge of cases in Egypt. From 2003 to October 2015, there have been a total of 844 laboratory-confirmed cases with mortality rates of

Table 4 Checklist for taking a travel history

\begin{tabular}{|c|c|}
\hline Questions & Examples \\
\hline $\begin{array}{l}\text { Country of travel and } \\
\text { accommodation }\end{array}$ & Latent diseases, possible exposures \\
\hline $\begin{array}{l}\text { Occupation, hobbies, } \\
\text { activities }\end{array}$ & $\begin{array}{l}\text { Healthcare worker, business, visiting relatives, } \\
\text { farmer, cave explorer, water exposure }\end{array}$ \\
\hline Prophylaxis & Immunizations, prophylaxis, insect repellents \\
\hline Treatment or procedures & Hospital treatment in country, tattoos \\
\hline Diet & Seafood, raw food \\
\hline Sex & Unprotected sex, paid sex, multiple partners \\
\hline Animals & Birds, domestic animals, wildlife \\
\hline
\end{tabular}

more than 50\% [19]. H7N9 is the most recently reported sub-type. It was first diagnosed in March 2013 in China and is characterized by rapidly progressive pneumonia, pulmonary failure and acute pulmonary distress syndrome (ARDS) [18]. As of October 2015, there have been 679 laboratory-confirmed cases, with 275 reported deaths [19].

Treatment of influenza remains a controversial topic but generally supportive management is adopted. Current recommendations are early administration of a neuraminidase inhibitor (e.g., oseltamivir) to the affected individual and their close contacts [18]. A recent meta-analysis of the H1N1 pandemic showed that hospitalized patients treated with a neuraminidase inhibitor had a lower mortality, and that this was further reduced by early instigation [20].

Prevention of avian influenza has proved difficult due to the antigenic diversity of the circulating viruses, which has hampered vaccine development [21]. Healthcare professionals should take post-exposure prophylaxis (e.g., oseltamivir) after a patient has been diagnosed with avian influenza and personal protective equipment is highly recommended.

\section{Severe acute respiratory syndrome (SARS) and Middle Eastern respiratory syndrome (MERS)}

Like influenza, other viral epidemics are gathering publicity, heightening awareness and recognition worldwide. MERS and SARS are zoonotic coronavirus infections with regular media coverage due to their symptom severity, associated mortality rates and anxiety regarding potential human-to-human transmission. Bats are thought to be the 
main intermediate host for both viruses, while there is compelling evidence that camels are also responsible for transmission of the MERS coronavirus [22, 23].

SARS was first reported as an atypical pneumonia to the World Health Organization (WHO) in November 2002 in China and subsequently spread worldwide. The first reported epidemic occurred in a Hong Kong hotel in February 2003. The virus was transmitted to 16 hotel guests who were staying on the same floor as an infected individual, and the virus spread through international air travel thereafter. WHO identified the coronavirus responsible through nasopharyngeal culture within 2 weeks of this event. More than 30 countries reported affected individuals, with more than 8,000 confirmed cases worldwide and a $9.6 \%$ mortality rate [24].

The pulmonary symptoms associated with SARS (typically, non-productive cough and subsequent dyspnea) did not present until several days after initial exposure to the virus. As SARS is caused by an airborne virus, the risk of transmission was greatest amongst those involved in the direct care of an infected individual. Since no medications effectively treated SARS, interrupting transmission was the key to controlling the outbreak. Simple public health measures, such as wearing surgical masks, offered the most effective protection against transmission and there were no further confirmed cases as of July 2003 [24].

The public health lessons learned during the SARS epidemic have proved invaluable in limiting the spread of MERS cases worldwide. MERS was first recognized in September 2012 and, as of October 2015, 1,611 cases have been reported with more than 570 related deaths [25]. To date, the largest cluster of cases to occur outside of the Middle East was reported in South Korea in May 2015. The index case was a businessman who developed pulmonary symptoms upon returning from a trip to the Middle East. A total of 185 cases were identified, with 36 deaths (19.5\% mortality rate) [26]. This proved the migrating capabilities of the virus and potential for outbreaks worldwide. Any clinician who sees an individual returning from the Middle East presenting with fever and pulmonary symptoms within 14 days of travel should consider MERS as a diagnosis and prompt investigations (diagnosed by nasopharyngeal culture) and public health control methods should be initiated. No specific treatments or vaccine have been developed to date.

As with most infections, the groups with the poorest outcomes related to MERS infection are the young ( $<12$ years), the elderly ( $>65$ years), immunocompromised patients and those with multiple co-morbidities [22]. Clinically, presentation is similar to SARS but MERS has a longer incubation period and greater severity of pulmonary symptoms and an even higher mortality risk. All cases of MERS confirmed worldwide to date have had a direct or indirect link with the Middle East-predominately Saudi Arabia. It has proven to be less contagious than SARS so far, although it is expected that a more virulent virus will evolve.

\section{The plague}

Where SARS and MERS have attracted much media coverage, it should not be forgotten that the plague bacillus (Yersinia pestis) still affects a great number of people each year [27]. The pneumonic plague has seen endemic outbreaks in certain parts of Africa, with sporadic cases occurring worldwide.

Historically, there have been 3 pandemics involving the bubonic (swollen, painful lymph nodes) and pneumonic plague in the 6th century, the 14th century and the 19th century; however, it also re-emerged in the 1990s with a more limited distribution [27].

The pneumonic plague occurs as a complication of the bubonic plague and is the only form capable of transmission from human-to-human via pulmonary droplets. Clinical sequelae are a dry cough within $24 \mathrm{~h}$ of first exposure, which becomes productive before hemoptysis occurs with the sputum becoming increasingly more bloodied within the next $24-48 \mathrm{~h}$-this is a sign of certain mortality. The major clinical clues in diagnosing the pneumonic plague are travel history, rapid onset of symptoms (sometimes hours from being asymptomatic to fever and cough/hemoptysis) and bilateral pneumonia $[27,28]$. The patient is most contagious when hemoptysis develops; simple protective measures, such as wearing masks, help prevent transmission [28].

The last reported outbreak of the pneumonic plague was in Madagascar in September 2014. There were 263 reported cases, with a $26.9 \%$ mortality rate. The plague has been endemic on the island for the past 30 years-it is the most severely affected country in the world [29].

While developing countries are at most risk of outbreaks of the disease, sporadic cases can occur elsewhere. Four patients were diagnosed in July 2014 with pneumonic plague in Colorado, United States of America (USA). The index patient contracted the disease from his pet dog. No deaths occurred and all patients rapidly responded to antibiotic treatment; streptomycin, tetracyclines and sulphonamides are used as the standard antibiotics, with gentamicin and fluoroquinolones as alternatives [30]. All close contacts should be given prophylactic antibiotics and monitored for symptoms.

The plague bacillus has previously been used in biological warfare during the 20th century. Yersinia Pestis is an attractive agent due to easy accessibility, simple culture needs and transmission via aerosol [31]. It is important point to note that a plague outbreak can be easily controlled with simple public health measures and readily 
available antibiotics; however, if inappropriately managed the pneumonic plague is almost certainly fatal.

\section{Hantaan and Nipah viruses}

Two viral infections noted to be causing outbreaks throughout the world are the Hantaan (causing hantavirus cardiopulmonary syndrome [HPS]) and Nipah viruses. Both diseases were microscopically discovered in the 1990s and are zoonotic; they are transmitted to humans via rodents and via bats and pigs, respectively. Both have a range of clinical symptoms and may present with flu-like symptoms continuing onto encephalitis with Nipah virus or pulmonary failure and cardiogenic shock in Hantavirus-related infections [32, 33].

The first Nipah outbreak was in Malaysia in 1999; a total of 276 cases were diagnosed with a $38.4 \%$ mortality rate [34]. The outbreak spread into Singapore and it was discovered that the virus was transmitted to humans from pigs; this resulted in a cull of more than 1 million pigs to control the outbreak. Since then, outbreaks have occurred in Bangladesh and India with a mortality rate of around 75\% [35]. Most cases presented with pulmonary symptoms (cough, dyspnea and bilateral opacities covering the majority of the lung fields on chest radiograph) and there was a higher human-to-human transmission rate in comparison to the Malaysian outbreak [36]. The Nipah virus was readily identified in the saliva of infected patients, allowing easy disease transmission.

There have only been outbreaks of the Nipah virus in South East Asia to date, but there is potential for this disease to occur in other countries. The intermediate host (fruit bats from the Pteropodidae family) has an extensive habitat distribution and is native to parts of Africa and northern Australia [37]. The treatment is limited to supportive care-control methods to prevent human-tohuman transmission are very important to stop rapid spread. Studies have shown the antiviral drug ribavirin may reduce mortality from the infection [33].

At present, more than 21 Hantaviruses from the Bunyaviridae family have been identified as causing illness in humans. Signs of infection range from proteinuria to pulmonary edema and frank hemorrhagic illnesses [32]. HPS is most likely to occur in the Americas although there are sporadic case reports from Europe [38]. The disease is most likely to be transmitted in areas where sanitation is poor or in rural farming areas. Rodents shed the virus in their urine, droppings and saliva, and the virus is transmitted between humans via pulmonary droplets [32].

The first reported outbreak occurred in 1993 in the USA, although retrospectively it seems the Hantaviruses have been causing fatal pulmonary illnesses since the 1950s [39]. The cluster of around 30 cases in 1993 occurred in an area of southwest USA known as the 'Four Corners'. Clinicians identified a series of cases of a severe and acute pulmonary illness affecting young healthy adults where non-cardiogenic pulmonary edema developed rapidly. To date, more than 600 cases of HPS have been reported in the USA [40]. In 2012, the virus was discovered at Yosemite National Park where potentially hundreds of travellers were exposed to the infection. Ten cases of HPS were confirmed, 3 of which were fatal [41].

Treatment for Hantavirus remains supportive. Intravenous fluids should be used with caution, as aggressive fluid resuscitation is likely to accelerate the progression to pulmonary edema and failure due to capillary leakage [32]. Extracorporeal membrane oxygenation (ECMO) treatment has dramatically reduced mortality rates [42]. The benefits of ribavirin therapy remain undetermined due to small trial numbers [43]. To date, only one Hantavirus has evolved to transmit via human-tohuman contact (the Andes virus, named after its geographical discovery location in 1996).

Accurate diagnosis requires a high degree of suspicion and should be considered in an individual presenting from a recent stay in North or South America with rapidly progressing pulmonary symptoms and/or signs [32]. The risk to a traveller in contracting any of the above outbreak diseases remains small given their limited geographical distribution at present. The risk of exposure may be increased by several factors (Table 1) such as activities undertaken, close contact with an infected individual, and not seeking appropriate pre-travel information or recommendations. As a clinician it is important to have up-to-date knowledge on current outbreaks occurring worldwide and their relevant geography as prompt recognition and diagnosis may prevent an epidemic.

\section{Q fever}

$\mathrm{Q}$ fever, caused by C. burnettii, is a worldwide zoonotic disease. Outbreaks in humans have been linked to abattoirs and carriage of C. burnettii by wind from farms of affected animals. Ticks can also act as a reservoir. It is not strictly a travel-related illness but it is most likely found in areas where contamination with animal waste is common. It presents as an acute febrile illness with non-specific signs such as atypical pneumonia [8]. Rural travelling is the greatest risk factor for acquiring the disease. Most recently, Q fever outbreaks have occurred in Hungary, where 70 cases were confirmed by microimmunofluorescence testing and treated with 3 weeks of a tetracycline. No deaths occurred. Efforts to reduce the spread of Q fever after an outbreak include elimination of manure and disinfection of affected farms [8].

\section{Legionella}

Legionella (L. pneumophila) is a bacterium that can cause anything from a mild febrile illness to the potentially fatal form of pneumonia known as Legionnaires' 
disease. The bacterium is ubiquitous in the environment, and the same agent causes sporadic cases and outbreaks. Outbreaks are typically linked to contaminated water systems where conditions are ideal for rapid growth of the organism [44]. In 2014, the WHO confirmed 302 cases of Legionellosis in Lisbon, Portugal, that were related to a contaminated industrial cooling tower, with 5 deaths as a result of the disease [45]. Most cases are reported after travel to developed countries in Europe or North America. At risk individuals are those with comorbidities, the elderly, smokers and the immunosuppressed. It is caused by inhalation of aerosols containing the bacterium and accounts for $2-15 \%$ of hospital admissions for community-acquired pneumonia, with a summer or autumn peak [45]. Identification of affected individuals is by urinary PCR and treatment is with a macrolide antibiotic [46].

\section{Pertussis and diphtheria}

Pertussis and diphtheria are vaccine-preventable pulmonary infections; poor vaccine uptake has led to a recent increase in cases in developed countries. It is important, therefore, to take a full vaccination history in returned travellers who present with pulmonary symptoms [47].

Pertussis is a worldwide endemic-epidemic disease with outbreaks most likely during summer/autumn time. Pertussis is thought to still cause around 63,000 deaths per year in children under 5 years of age, although there is uncertainty over these estimates in view of the paucity of reliable surveillance data [48].

Recently, there has been an increase in the number of adolescent and young adults being diagnosed in some high-income countries, likely due to decreased vaccination uptake rates and a change in the vaccine itself. It is thought that the acellular vaccine currently used appears to have a short-lived immunity leading to increased infection rates [49]. Macrolide antibiotics are given to affected individuals to prevent further spread of pertussis [49].

Diphtheria presents as an acute infectious disease affecting the upper pulmonary tract caused by toxins produced by the bacterium. Characteristic features are membranous pharyngitis with fever, enlarged anterior cervical lymph nodes and edema of the soft tissues of the neck [50]. This manifestation may lead to airway obstruction. The bacterium has a short incubation period but untreated individuals may remain infectious for up to 4 weeks. Both pertussis and diphtheria are potentially fatal but easily preventable.

\section{Leptospirosis}

Leptospirosis is contracted either through direct contact with infected animal urine, or urine-contaminated water [10]. It can be found worldwide, but is predominantly found in tropical and subtropical countries (during rainy season). Those taking part in water sports are most at risk (an outbreak was reported among canyoning participants in Martinique, France) [51]. Increased cases are also found in rural parts of a country where drinking water can be easily contaminated with the bacteria; for example, where wells have been poorly constructed [52]. Lately, there has been an increase in the number of cases noted in Europe, with 97 cases identified in the Netherlands in 2014 (4.6-fold increase in comparison to previous years). Dutch tourists reported 33 cases of leptospirosis, and most of these tourists acquired the disease in Thailand [53].

The clinical course of leptospirosis is variable, with symptoms from myalgia to fever with cough and shortness of breath. Weil's disease is its severest form and may develop in $1-5 \%$ of cases. Patients progress from mild flulike symptoms to signs of organ failure (jaundice and spontaneous bleeding) [54].

Where there is a high degree of clinical suspicion for leptospirosis, treatment should be instigated. Diagnosis is serological (via microscopic agglutination test [MAT] for antibodies or PCR urine antigen test) but it may take around 10 days after the onset of symptoms for these tests to become positive [10]. In early mild disease, penicillin and tetracycline antibiotics are effective [55]. Where the clinically more severe Weil's disease is manifest, patients may require organ support, and there is little evidence that antibiotic use is of any benefit at this stage [56]. In 2014, there were a total of 76 confirmed cases of leptospirosis in England and Wales, of which 22 were acquired overseas; the majority of these were related to recreational water exposure [57].

\section{Tularemia}

Recreational activities such as camping and visiting rural and agricultural areas lead to increased risk to exposure to the bacterium that causes tularemia [58]. Typically found in the Northern Hemisphere, the number of infected cases are underestimated and underreported [58]. Outbreaks have been reported on Martha's Vineyard (Massachusetts, USA), Sweden and Finland in the last 15 years [58].

Francisella tularensis is the bacterium responsible for what is a potentially fatal multi-systemic disease. Reservoirs of transmission are via ticks, biting flies, aerosol, water exposure and food [58]. There are 4 identified subtypes and clinical presentation depends on biotype, method of transmission and port of entry. There are 6 major clinical presentations: ulceroglandular, glandular, oculoglandular, oropharyngeal, pneumonic and typhoidal [58]. Pulmonary features may consist of lobar pneumonia, pulmonary effusions, infiltrates and hilar lymphadenopathy. Mortality in untreated pneumonic tularemia can be up to $60 \%$ [59]. 
Early diagnosis and treatment is key to prognosis, but isolation of the bacterium is hazardous and time consuming and most laboratories do not accept samples for culture [60]. Agglutination and enzyme-linked immunosorbent assay (ELISA) tests are the diagnostic tests of choice [58]. Aminoglycosides are bactericidal against $F$. tularensis and WHO recommend a 10-day course [61].

As an aside, F. tularensis subspecies tularensis (Type A) is one of the most infectious pathogens known to man, and these properties have led to tularemia being identified as a potential weapon of bioterrorism [60].

\section{Melioidosis}

In South East Asia and northern Australia, a particular Gram-negative organism called B. pseudomallei is responsible for an endemic of melioidosis disease [62]. Most commonly, the initial presentation is with lowgrade fever and atypical pneumonia, rapidly progressing to multi-organ dysfunction. The mortality rate is very high, ranging from 14 to $40 \%$ in general and up to $80 \%$ with inappropriate antimicrobial therapy [9]. Difficulties in culturing the bacterium responsible mean that underreporting is likely. The bacterium resides in soil and water with transmission occurring mainly from percutaneous inoculation and inhalation. Exposure is most likely to occur during the wet seasons in affected areas or after natural catastrophes such as tsunamis.

Sporadic cases of the infection are now being reported worldwide and manifestations of latent forms of the disease are appearing some tens of years after initial exposure [63]. As the number of international travellers continues to rise, particularly to more rural parts of South East Asia and northern Australia, this could lead to an increase in the number of travel-related melioidosis cases in the future.

Early recognition of melioidosis is essential as the bacterium is resistant to nearly all drugs given for community-acquired pneumonia [63]. Current treatment recommendations are ceftazidime or a carbapenem, followed by eradication therapy with trimethoprim and sulfamethoxazole for at least 3 months. There has been recent interest in vaccine development due to both public health and bioweapon concerns [64]. Mouse model vaccination has proved successful but to date there has been no testing on humans [64].

\section{Tuberculosis (TB)}

TB is a commonly found disease in certain parts of the world. The risk of TB as a travel-related disease has not been well established. A study from Italy in 2005 concluded that over half of returned travellers with pneumonia or TB presented with a febrile illness but no pulmonary symptoms [65]. TB can be transmitted on airplanes; a flight from Baltimore to Honolulu showed 4 of 15 passengers had a positive tuberculin skin test after sitting in close proximity to a passenger with pulmonary TB [6]. An overall probability of infection is 1 in 1,000 when a symptomatic source is present in close proximity [6].

Risk is linked to longer-term travel to areas of higher prevalence and proximity to affected individuals. Those most at risk would be healthcare workers or individuals visiting relatives [66]. TB risk in long-term travellers (of greater than 3 months) is the same as the local population in high endemic areas. A Dutch study showed there was substantial risk to long-term travellers with an overall incidence rate of 3.5 per 1,000 person-months travelled; however, no-one in this study had received a Bacillus Calmette-Guérin (BCG) vaccine prior to travelling, therefore incidence amongst those who have been vaccinated is likely to be lower [66].

In recent years, multidrug-resistant TB (MDR-TB) and extensively drug-resistant TB (XDR-TB) have become increasingly important public health problems in many countries (Eastern Europe, parts of Asia and Southern Africa) [67]. The potential risk of transmission of particularly dangerous forms of TB requires renewed vigilance. Since 2006, WHO have been informed of several incidences of patients travelling (short-haul) by air with MDR-TB and XDR-TB. In these cases, only close family members have been later diagnosed with the disease, but a potential risk to other travellers is possible given the infectious nature of these strains of TB [67]. WHO have since published guidelines for TB and air travel to prevent the spread of the disease [67].

The main advice to clinicians is that the number of TB infections is increasing, as are MDR-TB and XDR-TB disease. The risks to most travellers in contracting TB are small but increase depending on vaccination status, length of travel, mode of travel and travel destination. If pulmonary symptoms persist, despite negative standard microscopy, culture and sensitivity testing, TB should be added to the differential diagnosis list and should be investigated appropriately.

\section{Pulmonary infections caused by fungi}

Fungal infections in the absence of immunosuppression generally occur in the Americas, where the exact destination of the traveller plays an important role in distinguishing the fungus responsible.

\section{Histoplasmosis and coccidioidomycosis}

Histoplasmosis should be considered in travellers returning from the Midwest and central states of North America, throughout Latin America and Central and 
Western Africa [68-70]. In 2013, approximately 300 cases were reported in the South West region of China, the first to be reported in Asia [68].

Coccidioidomycosis (Valley fever) has long been recognized as a travel-related mycosis. Endemic areas are in Southern California, Arizona and Central and South America [69]. In returned travellers when common causes for flu-like illness, non-productive cough and pleuritic chest pain have been ruled out but symptoms continue to persist, an underlying fungal infection should be considered as a differential diagnosis.

Histoplasma capsulatum is endemic in North and Latin America, while $H$. dubiosii is mainly found in Central and Western Africa [70]. The organism grows in soils enriched with bat and bird droppings, and human infection generally occurs after dust inhalation of disturbed soil. The incubation period is relatively short, and symptoms develop within 2 weeks of exposure [69]. Reticulonodular shadowing on chest radiograph is common, often with mediastinal lymphadenopathy. Detection of the histoplasma antibody in urine or serum is the most sensitive and widely used diagnostic method [70]. Detection of coccidioidomycosis (Coccidioides immitis) is similar but radiologically a cavitating pneumonia may be seen [69].

In healthy individuals, fungal infections are generally self-limiting. In those who are immunocompromised, and/or go on to develop severe infection with systemic complications, antifungals have been proven to be effective [70]. In contrast to histoplasmosis, coccidioidomycosis infection generally leads to acquired immunity therefore recurrence is unlikely [69].

\section{Pulmonary infections caused by helminths}

Pulmonary symptoms such as wheeze, breathlessness and hemoptysis and an eosinophilia in a returned traveller should prompt investigations for helminths. These infections may present as Loeffler's syndrome (a result of larval migration through the lungs) or tropical pulmonary eosinophilia (hypersensitivity to lymphatic filarial worms). Specific to schistosomiasis infections, Katayama syndrome should be suspected in travellers returning from Africa or South East Asia with fresh water exposure presenting with fever, eosinophilia, dry cough and urticarial rash. Other rare pulmonary presentation of helminths infections (such as paragonimus, toxocariasis and dirofilariasis) should be considered depending on travel destination and incubation period [71]. Treatment of these infections is generally straightforward once the causative helminths have been identified.

In $20 \%$ of hydatidosis (echinococcosis tapeworm) there are pulmonary infiltrations. The majority of cases are asymptomatic but following a leaking hydatid cyst in the liver, patients may present with pleuritic chest pain, breathlessness and cough; a 'water lily' sign may be seen on chest radiograph [72]. Surgery (aspiration) and antiparasitic drugs are required to fully treat the infection.

\section{Conclusion}

The clinical spectrum of pulmonary infections in the returned traveller is vast. History taking is paramount (exact dates, contacts, length of stay, place of travel and timings of onset of symptoms) and a high degree of suspicion early on in the patient's management is vital. Most cases of pulmonary infections in travellers are mild and self-limiting but travel-specific pulmonary infections have high mortality rates if interventions are not prompt.

The main modes of transmission for pulmonary infections are by droplets or direct contact, hence the importance of implementing protective barriers and involving public health colleagues early to prevent further transmission. Advice is always available from online resources and specialist centers-as a clinician it is important to familiarize yourself with guidelines and protocols on travel-related infections. The WHO and Centers for Disease Control and Prevention (CDC) are continually updating guidelines on travel-related infections.

\section{Search strategy}

We identified references for this review by searches in different databases (PubMed, Ovid MEDLINE, Embase and Cochrane) and references from relevant articles. The following MeSH headings were used: "pulmonary", "respiratory", "tropical disease" 'travellers", "travel", "returning traveller".

The references were all further assessed by reading the title and abstract. Only articles published in English were included. We further assessed the references of all selected publications. The final reference list was generated on the basis of relevance to the topics covered in this review.

\section{Funding}

The authors have no support or funding to report.

\section{Authors' contributions}

All authors met ICMJE authorship criteria. AT, AC conceived and designed the research plan. AT, VM contributed to the acquisition, analysis and interpretation of the data. AT, VM, AC contributed equally to the writing of the first draft of the manuscript and writing of the manuscript. AT, VM, AC critically reviewed the manuscript for important intellectual content and agreed with the manuscript results and conclusions. All authors read and approved the final manuscript.

Competing interests

The authors declare that they have no competing interests.

Provenance

Commissioned; externally peer reviewed. 


\section{Text box}

\section{Where to look for help}

British Infection Association (BIA), for United Kingdom recommendations and guidelines: www.britishinfection.org/

Centers for Disease Control and Prevention (CDC): www.cdc.gov/

National Travel Health Network and Centre: www.nathnac.org/

ProMED-mail (electronic reporting system for infectious diseases outbreaks): www.promedmail.org/

Travax, United Kingdom NHS National Services Scotland website: http:// www.travax.nhs.uk

World Health Organization outbreak data: www.who.int/csr/don/en/

\section{Author details}

${ }^{1}$ Crosshouse Hospital, Kilmarnock Road, Crosshouse KA2 OBE, UK. ${ }^{2}$ Respiratory Infection Group, Liverpool School of Tropical Medicine, Pembroke Place, Liverpool L3 5QA, UK. ${ }^{3}$ Aintree Hospital, Longmoor Lane, Liverpool L9 7AL, UK. ${ }^{4}$ Respiratory Research Group, Royal Liverpool and Broadgreen University Hospital Trust, Prescot Street, Liverpool L7 8XP, UK.

Received: 10 December 2015 Accepted: 16 October 2016

Published online: 25 January 2017

\section{References}

1. UNWTO. Annual Report 2013. UNWTO; 2013. Available from: http://www2. unwto.org/publication/unwto-annual-report-2013. Accessed 1 Nov 2015.

2. Korzeniewski K, Nitsch-Osuch A, Lass A, Guzek A. Respiratory infections in travelers returning from the tropics. Adv Exp Med Biol. 2015;849:75-82. PMID:25381557, http://dx.doi.org/10.1007/55842014 89.

3. Hearn $P$, Johnston V. Assessment of returning travellers with fever. Medicine. 2014;42:66-72. doi:10.1016/j.mpmed.2013.11.009.

4. Gherardin A, Sisson J. Assessing fever in the returned traveller. Australian Prescriber An independent review. 2012;35(1):10.

5. Jennings LC, Priest PC, Psutka RA, Duncan AR, Anderson T, Mahagamasekera $P$, et al. Respiratory viruses in airline travellers with influenza symptoms: results of an airport screening study. J Clin Virol. 2015;67:8-13. PMID: 25959149, http://dx.doi.org/10.1016/j.jcv.2015.03.011.

6. Mangili A, Gendreau MA. Transmission of infectious diseases during commercial air travel. Lancet. 2005;365:989-96. PMID:15767002, doi:10.1016/ S0140-6736(05)71089-8.

7. Ansart S, Pajot O, Grivois JP, Zeller V, Klement E, Perez L, et al. Pneumonia among travelers returning from abroad. J Travel Med. 2004;11:87-91. PMID: 15109472, http://dx.doi.org/10.2310/7060.2004.17055.

8. Gyuranecz M, Sulyok K, Balla E, Mag T, Balazs A, Simor Z, et al. Q fever epidemic in Hungary, april to july 2013. Euro Surveill. 2014;19. PMID: 25108535, http://dx.doi.org/10.2807/1560-7917.ES2014.19.30.20863.

9. Saïdani N, Griffiths K, Million M, Gautret P, Dubourg G, Parola P, et al. Melioidosis as a travel-associated infection: case report and review of the literature. Travel Med Infect Dis. 2015;13:367-81. PMID:26385170, http://dx. doi.org/10.1016/j.tmaid.2015.08.007.

10. Johnston V, Stockley JM, Dockrell D, Warrell D, Bailey R, Pasvol G, British Infection Society and the Hospital for Tropical Diseases, et al. Fever in returned travellers presenting in the United Kingdom: recommendations for investigation and initial management. J Infect. 2009;59:1-18. PMID: 19595360, http://dx.doi.org/10.1016/j.jinf.2009.05.005.

11. Cadorna-Carlos JB, Nolan T, Borja-Tabora CF, Santos J, Montalban MC, de Looze FJ, et al. Safety, immunogenicity, and lot-to-lot consistency of a quadrivalent inactivated influenza vaccine in children, adolescents, and adults: a randomized, controlled, phase III trial. Vaccine. 2015;33:2485-92. PMID:25843270, http://dx.doi.org/10.1016/j.vaccine.2015.03.065.

12. Sridhar S, Belhouchat K, Drali T, Benkouiten S, Parola P, Brouqui P, et al. French Hajj pilgrims' experience with pneumococcal infection and vaccination: a knowledge, attitudes and practice (KAP) evaluation. Travel
Med Infect Dis. 2015;13:251-5. PMID:25725996, http://dx.doi.org/10.1016/j. tmaid.2015.02.002.

13. Leder K, Sundararajan V, Weld L, Pandey P, Brown G, Torresi J, Groupa GSS. Respiratory tract infections in travelers: a review of the GeoSentinel surveillance network. Clin Infect Dis. 2003;36:399-406. PMID:12567296, http://dx.doi.org/10.1086/346155.

14. O'Brien DP, Leder K, Matchett E, Brown GV, Torresi J. Illness in returned travelers and immigrants/refugees: the 6-year experience of two Australian infectious diseases units. J Travel Med. 2006;13:145-52. PMID:16706945, http://dx.doi.org/10.1111/j.1708-8305.2006.00033.x.

15. Ratnam I, Black J, Leder K, Biggs BA, Gordon I, Matchett E, et al. Incidence and risk factors for acute respiratory illnesses and influenza virus infections in Australian travellers to Asia. J Clin Virol. 2013;57:54-8. PMID:23380660, http://dx.doi.org/10.1016/j.jcv.2013.01.008.

16. Sankari T, Hoti SL, Govindaraj V, Das PK. Chikungunya and respiratory viral infections. Lancet Infect Dis. 2008:8:3-4. PMID:18156080, doi:10.1016/S14733099(07)70295-5.

17. Harper SA, Fukuda K, Uyeki TM, Cox NJ, Bridges CB, Centers for Disease Control and Prevention (CDC) Advisory Committee on Immunization Practices (ACIP). Prevention and control of influenza: recommendations of the Advisory Committee on Immunization Practices (ACIP). MMWR Recomm Rep. 2004;53(RR-6):1-40. PMID:15163927.

18. Li Q, Zhou L, Zhou M, Chen Z, Li F, Wu H, et al. Epidemiology of human infections with avian influenza A(H7N9) virus in China. N Engl J Med. 2014; 370:520-32. PMID:23614499, http://dx.doi.org/10.1056/NEJMoa1304617.

19. Influenza at the human-animal interface: World Health Organization. Available from: http://www.who.int/influenza/human_animal_interface/ about/en/. Accessed 10 May 2016.

20. Muthuri SG, Venkatesan S, Myles PR, Leonardi-Bee J, Al Khuwaitir TS, Al Mamun A, PRIDE Consortium Investigators, et al. Effectiveness of neuraminidase inhibitors in reducing mortality in patients admitted to hospital with influenza A H1N1pdm09 virus infection: a meta-analysis of individual participant data. Lancet Respir Med. 2014;2:395-404. PMID: 24815805, doi:10.1016/\$2213-2600(14)70041-4.

21. Hala IA, Nagwa FE. Human pandemic threat by H5N1 (avian influenza). Afr J Microbiol Res. 2014;8:406-10. http://dx.doi.org/10.5897/AJMR10.303.

22. Al-Tawfiq JA, Zumla A, Memish ZA. Travel implications of emerging coronaviruses: SARS and MERS-CoV. Travel Med Infect Dis. 2014;12:422-8. PMID:25047726, http://dx.doi.org/10.1016/j.tmaid.2014.06.007.

23. Hui DS, Memish ZA, Zumla A. Severe acute respiratory syndrome vs. the Middle East respiratory syndrome. Curr Opin Pulm Med. 2014;20:233-41. PMID:24626235, http://dx.doi.org/10.1097/MCP.0000000000000046.

24. Parashar UD, Anderson LJ. Severe acute respiratory syndrome: review and lessons of the 2003 outbreak. Int J Epidemiol. 2004;33:628-34. PMID: 15155694, http://dx.doi.org/10.1093/ije/dyh198.

25. WHO. Middle East respiratory syndrome coronavirus (MERS-CoV): World Health Organization; 2015. [Updated 2015-12-05 00:11:04]. Available from: http://www.who.int/emergencies/mers-cov/en/. Accessed 1 Nov 2015

26. WPRO. Middle East respiratory syndrome coronavirus (MERS-CoV): WPRO | WHO Western Pacific Region; 2015 [updated 2015-09-13 08:54:51. Available from: http://www.wpro.who.int/outbreaks_emergencies/wpro_ coronavirus/en/. Accessed 1 Nov 2015.

27. Stenseth NC, Atshabar BB, Begon M, Belmain SR, Bertherat E, Carniel E, et al. Plague: past, present, and future. PLoS Med. 2008;5, e3. PMID:18198939, http://dx.doi.org/10.1371/journal.pmed.0050003.

28. Kool JL. Risk of person-to-person transmission of pneumonic plague. Clin Infect Dis. 2005;40:1166-72. PMID:15791518, http://dx.doi.org/10. $1086 / 428617$

29. WHO. Plague in Madagascar: World Health Organization; 2015. [updated 2015-06-21 07:05:15.] Available from: http://www.who.int/csr/disease/ plague/madagascar-outbreak/en/. Accessed 10 Nov 2015.

30. Runfola JK, House J, Miller L, Colton L, Hite D, Hawley A, Centers for Disease Control and Prevention (CDC), et al. Outbreak of human pneumonic plaque with dog-to-human and possible human-to-human transmission-Colorado, june-july 2014. MMWR Morb Mortal Wkly Rep. 2015;64:429-34. PMID: 25928467.

31. Prentice MB, Rahalison L. Plague. Lancet. 2007;369:1196-207. PMID: 17416264, doi:10.1016/S0140-6736(07)60566-2.

32. Jonsson CB, Figueiredo LT, Vapalahti O. A global perspective on hantavirus ecology, epidemiology, and disease. Clin Microbiol Rev. 2010;23:412-41. PMID:20375360, http://dx.doi.org/10.1128/CMR.00062-09. 
33. Chong HT, Kamarulzaman A, Tan CT, Goh KJ, Thayaparan T, Kunjapan SR, et al. Treatment of acute Nipah encephalitis with ribavirin. Ann Neurol. 2001;49:810-3. PMID:1 1409437, http://dx.doi.org/10.1002/ana.1062.

34. Chua KB, Lam SK, Goh KJ, Hooi PS, Ksiazek TG, Kamarulzaman A, et al. The presence of Nipah virus in respiratory secretions and urine of patients during an outbreak of Nipah virus encephalitis in Malaysia. J Infect. 2001;42: 40-3. PMID:11243752, http://dx.doi.org/10.1053/jinf.2000.0782.

35. SEARO. Nipah virus outbreaks in the WHO South-East Asia Region: SEARO WHO South-East Asia Region; 2013. [updated 2013-02-11 12:10:49]. Available from: http://www.searo.who.int/entity/emerging_diseases/links/nipah_virus_ outbreaks_sear/en/. Accessed 20 Nov 2015.

36. Luby SP, Gurley ES, Hossain MJ. Transmission of human infection with Nipah virus. Clin Infect Dis. 2009;49:1743-8. PMID:19886791, http://dx.doi.org/10. 1086/647951.

37. Global_NiphaandHendraRisk_20090510.png (2027Ã_1358): World Health Organization; 2015. Available from: http://www.searo.who.int/entity/emerging diseases/links/information_regarding_nipah_virus/en/. Accessed 20 Nov 2015.

38. Gizzi M, Delaere B, Weynand B, Clement J, Maes P, Vergote V, et al. Another case of "European hantavirus pulmonary syndrome" with severe lung, prior to kidney, involvement, and diagnosed by viral inclusions in lung macrophages. Eur J Clin Microbiol Infect Dis. 2013;32:1341-5. PMID: 23670277, http://dx.doi.org/10.1007/s10096-013-1885-x.

39. Zaki SR, Khan AS, Goodman RA, Armstrong LR, Greer PW, Coffield LM, et al. Retrospective diagnosis of hantavirus pulmonary syndrome, 1978-1993: implications for emerging infectious diseases. Arch Pathol Lab Med. 1996; 120:134-9. PMID:8712893.

40. CDC - Reported Cases of HPS - Hantavirus: centre for disease control. 2015. Available from: http://www.cdc.gov/hantavirus/surveillance/index.html. Accessed 20 Nov 2015

41. Hartline J, Mierek C, Knutson T, Kang C. Hantavirus infection in North America: a clinical review. Am J Emerg Med. 2013;31:978-82. PMID: 23680331, http://dx.doi.org/10.1016/j.ajem.2013.02.001.

42. Crowley MR, Katz RW, Kessler R, Simpson SQ, Levy H, Hallin GW, et al. Successful treatment of adults with severe Hantavirus pulmonary syndrome with extracorporeal membrane oxygenation. Crit Care Med. 1998;26:409-14. PMID:9468181, http://dx.doi.org/10.1097/00003246-199802000-00047.

43. Mertz GJ, Miedzinski L, Goade D, Pavia AT, Hjelle B, Hansbarger CO, Collaborative Antiviral Study Group, et al. Placebo-controlled, double-blind trial of intravenous ribavirin for the treatment of hantavirus cardiopulmonary syndrome in North America. Clin Infect Dis. 2004;39:130713. PMID:15494907, http://dx.doi.org/10.1086/425007.

44. Falkinham 3rd JO, Hilborn ED, Arduino MJ, Pruden A, Edwards MA. Epidemiology and ecology of opportunistic premise plumbing pathogens: Legionella pneumophila, Mycobacterium avium, and Pseudomonas aeruginosa. Environ Health Perspect. 2015;123:749-58. PMID:25793551.

45. Sakamoto R. Legionnaire's disease, weather and climate. Bull World Health Organ. 2015;93:435-6. PMID:26240466, http://dx.doi.org/10.2471/BLT.14.142299.

46. Managing legionella in hot and cold water systems: health and safety executive. 2015. Available from: http://www.hse.gov.uk/healthservices/ legionella.htm. Accessed 22 Nov 2015.

47. Larson HJ, Cooper LZ, Eskola J, Katz SL, Ratzan S. Addressing the vaccine confidence gap. Lancet. 2011;378:526-35. PMID:21664679, doi:10.1016/ S0140-6736(11)60678-8.

48. WHO. Pertussis vaccines: WHO position paper - september 2015. Wkly Epidemiol Rec. 2015;90:433-58. PMID:26320265.

49. Carbonetti NH. Bordetella pertussis: new concepts in pathogenesis and treatment. Curr Opin Infect Dis. 2016;29:287-94. PMID:26906206, doi:10. 1097/QCO.0000000000000264.

50. Burkovski A. Diphtheria and its etiological agents. In: Burkovski A, editor. Corynebacterium diphtheriae and related toxigenic species. Erlangen: Springer Netherlands; 2014. p. 1-14. doi:10.1007/978-94-077-7624-1_1.

51. Hochedez P, Escher M, Decoussy H, Pasgrimaud L, Martinez R, Rosine J, et al. utbreak of leptospirosis among canyoning participants, Martinique, 2011. Euro Surveill. 2013;18:20472. PMID:23725775.

52. Wynwood SJ, Graham GC, Weier SL, Collet TA, McKay DB, Craig SB. Leptospirosis from water sources. Pathog Glob Health. 2014;108:334-8. PMID:25348115, doi:10.1179/2047773214Y.0000000156.

53. Pijnacker R, Goris MG, Te Wierik MJ, Broens EM, van der Giessen JW, de Rosa $M$, et al. Marked increase in leptospirosis infections in humans and dogs in the Netherlands, 2014. Euro Surveill. 2016;21. PMID:27168584, http://dx.doi. org/10.2807/1560-7917.ES.2016.21.17.30211.
54. Health Care Workers | Leptospirosis | CDC: Centre for Disease Control. 2015. Available from: http://www.cdc.gov/leptospirosis/health_care_workers/ index.html. Accessed 22 Nov 2015.

55. Katz AR, Ansdell VE, Effler PV, Middleton CR, Sasaki DM. Assessment of the clinical presentation and treatment of 353 cases of laboratory-confirmed leptospirosis in Hawaii, 1974-1998. Clin Infect Dis. 2001;33:1834-41. PMID: 11692294, http://dx.doi.org/10.1086/324084.

56. Brett-Major DM, Coldren R. Antibiotics for leptospirosis. Cochrane Database Syst Rev. 2012;2, CD008264. PMID:22336839.

57. Common animal associated infections quarterly report (England and Walesfourth quarter 2014): Public Health England; 2015. Available from: https:// www.gov.uk/government/publications/common-animalassociatedinfections-quarterly-reports-2015. Accessed 22 Nov 2015.

58. Ulu-Kilic A, Doganay M. An overview: tularemia and travel medicine. Travel Med Infect Dis. 2014;12(6 Pt A):609-16. PMID:25457302, http://dx.doi.org/10. 1016/j.tmaid.2014.10.007

59. Cowley SC. Editorial: proinflammatory cytokines in pneumonic tularemia: too much too late? J Leukoc Biol. 2009;86:469-70. PMID:19720615, http://dx.doi.org/10.1189/jlb.0309119.

60. Tärnvik A, Chu MC. New approaches to diagnosis and therapy of tularemia. Ann N Y Acad Sci. 2007;1105:378-404. PMID:17468229, http://dx.doi.org/10. 1196/annals.1409.017.

61. Clinicians | Tularemia | CDC: Centre for Disease Control. 2015. Available from: http://www.cdc.gov/tularemia/clinicians/index.html. Accessed $10 \mathrm{Nov}$ 2015

62. Hoffmaster AR, Aucoin D, Baccam P, Baggett HC, Baird R, Bhengsri S, et al. Melioidosis diagnostic workshop, 2013. Emerg Infect Dis. 2015;21. PMID: 25626057.

63. Fisher DA, Harris PN. Melioidosis: refining management of a tropical time bomb. Lancet. 2014;383:762-4. PMID:24284288, doi:10.1016/S01406736(13)62143-1.

64. Limmathurotsakul D, Funnell SG, Torres AG, Morici LA, Brett PJ, Dunachie S et al. Steering group on melioidosis vaccine development. Consensus on the development of vaccines against naturally acquired melioidosis. Emerg Infect Dis. 2015;21. PMID:25992835, http://dx.doi.org/10.3201/eid2106.141480.

65. Matteelli A, Beltrame A, Saleri N, Bisoffi Z, Allegri R, Volonterio A, SIRL Study Group, et al. Respiratory syndrome and respiratory tract infections in foreign-born and national travelers hospitalized with fever in Italy. J Travel Med. 2005;12:190-6. PMID:16086893, http://dx.doi.org/10.2310/ 7060.2005 .12404

66. Cobelens FG, van Deutekom H, Draayer-Jansen IW, Schepp-Beelen AC, van Gerven PJ, van Kessel RP, et al. Risk of infection with Mycobacterium tuberculosis in travellers to areas of high tuberculosis endemicity. Lancet. 2000;356:461-5. PMID:10981889, doi:10.1016/S0140-6736(00)02554-X.

67. Martinez L, Blanc L, Nunn P, Raviglione M. Tuberculosis and air travel: WHO guidance in the era of drug-resistant TB. Travel Med Infect Dis. 2008;6:17781. PMID:18571104, http://dx.doi.org/10.1016/j.tmaid.2007.10.004.

68. Pan B, Chen M, Pan W, Liao W. Histoplasmosis: a new endemic fungal infection in China? Review and analysis of cases. Mycoses. 2013;56:212-21. PMID:23216676, http://dx.doi.org/10.1111/myc.12029.

69. Panackal AA, Hajjeh RA, Cetron MS, Warnock DW. Fungal infections among returning travelers. Clin Infect Dis. 2002;35:1088-95. PMID:12384843, http:// dx.doi.org/10.1086/344061.

70. Information for Health Professionals about Histoplasmosis | Types of Diseases | Histoplasmosis | Fungal Disease | CDC: Centre for Disease Control. 2015. Available from: http://www.cdc.gov/fungal/diseases/histoplasmosis/ health-professionals.html. Accessed 10 Nov 2015.

71. Checkley AM, Chiodini PL, Dockrell DH, Bates I, Thwaites GE, Booth HL, British Infection Society and Hospital for Tropical Diseases, et al. Eosinophilia in returning travellers and migrants from the tropics: UK recommendations for investigation and initial management. J Infect. 2010;60:1-20. PMID: 19931558, http://dx.doi.org/10.1016/j.jinf.2009.11.003.

72. Kunst H, Mack D, Kon OM, Banerjee AK, Chiodini P, Grant A. Parasitic infections of the lung: a guide for the respiratory physician. Thorax. 2011;66: 528-36. PMID:20880867, http://dx.doi.org/10.1136/thx.2009.132217. 